\title{
The Effectivenees of Management and Administration Sekolah Menengah Imtiaz Yayasan Terengganu (Smiyt) to Student Academic Excellence
}

\author{
Mohd Zainudin Bin Harun', Sulaiman Yamin², and Y.M Dato' Tengku Mahmud Bin Mansor ${ }^{3}$ \\ \{zainudinucb@gmail.com ${ }^{1}$ \} \\ ${ }^{1,2,3}$ University College Bestari, Terengganu, Malaysia
}

\begin{abstract}
Abstrak: In this era the development of a country is largely depend on the progress of thinking and the ability of human capital to be generated by its educational system. Malaysia wants to drive a knowledge-based economy, will definitely require first-class human capital. The Ulul-Albab curriculum is a big contributor to the paradigm shift in the Malaysians educational system. The Sekolah Menengah IMTIAZ Yayasan Terengganu is using the Ulul-Albab curriculum. It operates in eight districts which include Besut, Dungun, Kuala Berang, Kuala Terengganu, Kemaman, Kuala Nerus, Setiu dan Marang. The Ulul-Albab curriculum is an integrated educational curriculum which comprise pure science programs with religious programs including the Tahfiz al-Quran. The Ulul-Albab curriculum aims to produce professional and entrepreneurs who are not only knowledgeable but have proficiency in the field of religion based on the Quran and alSunnah as Ulul-Albab generation. The main objective of the Ulul-Albab Curriculum is to produce the Ulul-Albab generation which features three components namely Quranic, Encyclopedic and Ijtihadik. The Ulul-Albab learning method is Super Learning, compacting syllabus with wide Enrichment Model Methods and personality development to the students. The program include parental involvement, Community programs and supplementary diet with sunnah food. In an era of an increasingly advanced and challenging education world, the government aims to produce 125,000 professional memorizes in various fields by 2050. In high school Imtiaz Besut it was found that the Quranic memorization has a positive impact on student academic excellence based on comparative analysis of SPM achievement from 2012 to 2017, The implication of this study concluded that the memorizing activities of the Quran should be addressed and blended in academic field as the Quranic memorization also contributes to student academic excellence.
\end{abstract}

Keywords: Ulul-Albab curriculum, Sekolah Menengah IMTIAZ Yayasan Terengganu, Quranic, Encyclopedic and Ijtihadik

\section{Introduction}

Sekolah Menangah IMTIAZ Yayasan Terengganu (SMIYT) is registered with the Ministry of Education Malaysia and is the first elite school under the Terengganu State Government. SMIYT is using the Ulul-Albab curriculum. It operates in eight districts which include Besut, Dungun, Kuala Berang, Kuala Terengganu, Kemaman, Kuala Nerus, Setiu dan Marang. The Ulul-Albab curriculum is an integrated educational curriculum which comprise pure science programs with religious programs including the Tahfiz al-Quran. The Ulul-Albab curriculum aims to produce professional and entrepreneurs who are not only knowledgeable but have proficiency in the field of religion based on the Quran and Sunnah as Ulul-Albab generation.. The school offers education in parallel with the national education system of 
science that is integrated in conjunction with Quran recitation and religious education. This school is managed by management division of Yayasan Terengganu.

\section{Literature Review}

The Ulul-Albab definition has the Quran as the basis of the of Ulul-Albab. The UlulAlbab generation is a group that has a strong foundation in the Quran, a wide and diverse range of knowledge, capable of thinking and observing God's events through the eyes, hearts and intellects, practicing and taking lessons from it. ALBAB's Word in the context of Language is a plural form of "LUBB" which carries the meaning of heart.

Objective Ulul-Albab, first produce a generation of Quran who is believing, devout, knowledgeable, noble, skilled, responsible and devoted to religion, race and nation. Secondly, produce students who are based on science and Quran scholars who can qualify for professional and technical studies in any of the world's most famous universities. Third, producing students who can memorize the Quran by 30 juzuk within 3 years of study and build the Quranic culture of the Quran with the latest technology approach. Fourth, produce the generation of Quran that dominates the world of languages such as Malay, English, Arabic and Japanese.

Ulul-Albab Vision, produced the Ulul-Albab generation who understood Quran-based Quranic, Encyclopedic and Ijtihadic and also understand science, philosophy and technology to face the challenges of globalization and achieve the glorious of the ummah. The Ulul-Albab Mission, to produce human, religious, intellectual, noble, skillful, responsible and devoted Muslims, nations and countries through the creation of the Quran. The Ulul-Albab Curriculum is a Ulul-Albab program that maintains an existing curriculum with an additional Quran recitation program. Students who follow the Ulul-Albab curriculum will have three main features namely Quranic, Encyclopedic and Ijtihadik.

The Quranic feature is that students need to memorize 30 Quran verses and understand the Quran claim as the source of the highest knowledge based on the concept of read, remember, understand, think, charity and spread with emphasis on the teaching of the Quran is the smoothness of tajwid and makhraj and to give understanding about responsibility to study in Islam and tauhid to Allah S.W.T. Through the system of memorization one page a day a juz per month and 10 juzuk a year during form one and memorize $30 \mathrm{Al}$-Quran verses during form 3 and each one verses Al-Quran guarded by a teacher.

The Encyclopedic feature requires highly knowledgeable and highly skilled students and can be a reference point in various disciplines and able to master multiple languages to facilitate mastery of the knowledge and reference of the ummah.

The Ijtihadik also requires students to give insights into the problem of self, family, society, nation and ummah by maximizing brain and mind capacity, thinking creatively and innovatively and capable of applying high technology for the purpose of building human civilization and contributing to the prosperity of God Almighty earth according to human beings as leader on this earth with the Quran as a guide and guidance.

The curriculum used is still an integrated secondary school curriculum (KBSM), which Science, Religion and Hafazan are integrated in concert and simultaneously. While CoCurriculum is an activity run by qualified and experienced trainers.

The SMIYT learning method is the Super Learning Method, the Ulul-Albab Foundation Special Program which contains drill exercises, compacting syllabus and School wide Enrichment Model. The Super Learning is the ability to learn an immense amount of 
information in a fairly short amount of time. It involves speed reading, memorization through various methods such as psychological markers, memorize and spaced repetition.

The School wide Enrichment Development Model (SEM), implemented as an enrichment program used for academic talented students and develops talents of all students. SEM's ultimate goal is the application of educational pedagogy to school improvement. SEM provides enriched learning experiences and higher learning standards for all children through three goals; develop talent in all children, provide high level enrichment experience for all students, and provide more advanced follow up opportunities for young people based on their strengths and interests. SEM focuses on enriching for all students through high levels of engagement and the use of fun and challenging learning experiences built around student interests, learning styles, and preferred expression styles.

Student Personality Development, SMIYT students often face problems to create good social relationships. They like to work alone, do not like being part of peer groups and are not easily subject to cultural demands. In this context, students need coaching to socialize with peers and adults, but not compliant with the will of others blindly. On the contrary, they need to learn independently without segregating themselves from society. SMIYT embraces personality development to students including self-motivation, spirituality and leadership.

Parental Involvement, MIYT usually identifies the skills available to parents. Every parent's skills will be used for the development of student education and collaboration from parents to help students in academic achievement. Parents are allowed to visit students at any time and 24-hour open hostel to be visited by parents.

Community Programs, Community Programs are community work carried out in groups and have the aims and objectives to ease the burden, benefits, and well-being of the community. MIYT students are encouraged to participate in a collective and periodical community program to provide results and impact to the receiving community and is an extremely important activity to foster goodwill among communities and MIYTs. Among the activities that have been carried out are funeral prayers, grave pilgrimage and welfare home visits. Supplementary Foods, We all know it's important for parents to supplement food for students. It is important for physical growth and brain development and even student IQ. As a child, your child's body grows rapidly and his brain grows up to 3 times when he is 3 years old. The childhood phase is the most important moment in the cognitive development of a human being. It relates to his thinking skills, memory, and focus. All of these developments require your child to receive adequate nutritional supplements. The supplementary foods available at MIYT are fresh milk, dates and honey.

\section{Ulul-Albab Program Implementation}

Ulul-Albab Program Implementation, Students at SMIYT are required to follow the Muqarrar Tahfiz syllabus, a special syllabus for form one to three. Each level has two universes. One universe for one form, the student is obliged to memorize four surah and five constituencies is surah al-Sajadah, Yaasin, al-Dukhan, al-mulk and one to five juzuk. The double universe for a single form, the student is obliged to memorize six constituencies is the sixth to the sixth. The universe is one of two forms, students are obliged to memorize six constituencies is twelve to seventeen. The double universe for form two, the student is obliged to memorize six constituencies is eighteen to twenty-three. The universe is one of three forms, students are obliged to memorize six constituencies is twenty-four to twenty-ninth. The double universe for the form three, the student is obliged to memorize one constituency is the thirty to thirty. To memorize the Quran, the students are given two memorable hours, beginning half an hour before the Subuh prayers and continuing after the Subuh prayers until 6.45am and after 
the Magrib prayers until $9.00 \mathrm{pm}$. Teaching and learning for the first semester, all semester 1 students are required to follow the prescribed syllabus as follows:
a. Quran memorizer
b. English Communication skills
c. Basic Mathematical Skills
d. Mind Map Skills
e. Thinking Skills
f. Basic science skills
g. Islamic charity skills
h. Arabic Language skills
i. $\quad$ Speed Reading skills
j. $\quad$ Public Speaking Skills

Table 1. Student Daily Schedule

\begin{tabular}{ll}
\hline Times & Activities \\
\hline $5.00 \mathrm{am}$ & $\begin{array}{l}\text { Wake up in the morning / } \\
\text { memorizer class (30 minutes } \\
\text { before Subuh prayers) }\end{array}$ \\
\hline $5.15-6.00 \mathrm{am}$ & $\begin{array}{l}\text { Subuh prayers / Al-Quran } \\
\text { memorizer class }\end{array}$ \\
\hline $6.00-6.45 \mathrm{am}$ & Writing class \\
\hline $7.00-7.20 \mathrm{am}$ & Breakfast \\
\hline $7.20-7.40 \mathrm{am}$ & Roll call / rest \\
\hline $7.40-9.00 \mathrm{am}$ & Al-Quran class \\
\hline $12.00-12.00 \mathrm{am}$ & Daily class \\
\hline $2.00-2.00 \mathrm{pm}$ & $\begin{array}{l}\text { Lunch / Zohor prayers / sleep in } \\
\text { a set time }\end{array}$ \\
\hline $2.40-3.40 \mathrm{pm}$ & Revision class \\
\hline $3.40-4.40 \mathrm{pm}$ & Daily class \\
\hline $4.40-5.00 \mathrm{pm}$ & Asar prayers \\
\hline $5.00-5.30 \mathrm{pm}$ & Revision class \\
\hline $5.30-6.30 \mathrm{pm}$ & Sport / recreation \\
\hline $6.30-7.30 \mathrm{pm}$ & Dinner / Magrib prayers \\
\hline $7.30-9.00 \mathrm{pm}$ & $\begin{array}{l}\text { Al-Quran memorizer class / } \\
\text { Isyak prayers }\end{array}$ \\
\hline $9.00-10.30 \mathrm{pm}$ & Preparatory class \\
\hline $10.30-10.45$ & Supper \\
\hline $11.30 \mathrm{pm}$ & Light off / sleep \\
\hline
\end{tabular}

\section{Methodology}

To determine the level of student achievement, students will be evaluated in written and verbal memorization. The weighted scores are as follows:
a. Written $30 \%$
b. Oral $70 \%$ 
Admission requirements to IMTIAZ must earn 3A3B in the UPSR exam. The evaluation and selection of candidates will be made through the interview. Things to test during the interview are as follows:
a. The ability to read al-Quran
b. The ability to memorize the al-Quran
c. Jawi skills
d. The ability to communicate in Malay and English
e. Attitude test, science and mathematics

\section{Result And Discussion}

\begin{tabular}{|c|c|c|c|c|c|c|c|c|c|c|c|c|}
\hline \multicolumn{10}{|c|}{ OUTCOME OF A SPM 2017} \\
\hline & $11 \mathrm{~A}$ & $10 \mathrm{~A}$ & $9 \mathrm{~A}$ & $8 \mathrm{~A}$ & $7 \mathrm{~A}$ & $6 \mathrm{~A}$ & $5 \mathrm{~A}$ & $4 \mathrm{~A}$ & $3 \mathrm{~A}$ & $2 \mathrm{~A}$ & $1 \mathrm{~A}$ & $0 \mathrm{~A}$ \\
\hline STUDENT & 22 & 10 & 13 & 9 & 10 & 20 & 10 & 6 & 0 & 0 & 0 & 0 \\
\hline
\end{tabular}

Fig.1. Analysis of Achievement Excellence Number A SPM 2017 (IMTIAZ BESUT 2017 REPORT ANALYSIS)

\begin{tabular}{|c|c|c|c|c|c|c|c|c|c|c|c|c|c|}
\hline \multicolumn{14}{|c|}{ OUTCOMH A SIM 2012 - 2017} \\
\hline & $11 \mathrm{~A}$ & $10 \mathrm{~A}$ & $9 \mathrm{~A}$ & $8 \mathrm{~A}$ & $7 \mathrm{~A}$ & $6 \mathrm{~A}$ & $5 \Lambda$ & $4 A$ & $3 A$ & $2 \lambda$ & $1 \mathrm{~A}$ & $O A$ & CANDIDATL \\
\hline 2012 & 13 & 4 & 5 & 4 & 5 & 2 & 3 & 4 & 2 & 1 & 1 & 0 & 44 \\
\hline 2013 & 11 & 3 & 6 & 4 & 5 & 7 & 1 & 5 & 4 & 3 & 1 & 0 & 50 \\
\hline 2014 & 16 & 1 & 7 & 6 & 4 & 1 & 5 & 7 & 0 & 1 & 0 & 0 & 51 \\
\hline 2015 & 12 & 17 & 17 & 11 & 11 & 12 & 5 & 3 & 1 & 0 & 0 & 0 & 89 \\
\hline 2016 & 3 & 3 & 5 & 7 & 6 & 10 & 5 & 8 & 4 & 6 & 2 & 0 & $s 9$ \\
\hline 2017 & 22 & 10 & 13 & 9 & 10 & 20 & 10 & 6 & 0 & 0 & 0 & 0 & 100 \\
\hline
\end{tabular}

Fig.2. Analysis of Achievement Excellent Number of A SPM 2012 - 2017

The view of former Higher Education Minister, Datuk Seri Idris Jusoh on at least one Ulul-Albab school in each state is an appropriate and wise step. Modification of the curriculum in stages in primary and secondary is to produce a balanced and harmonious generation as revealed in the national education philosophy. Ulul-Albab is based on three main companions namely the Quranic, Encyclopedic and Ijtihadic towards producing a balanced generation in terms of academic excellence, religious knowledge and Islamic personality. The Ulul-Albab program will further strengthen the Jawi, Al-Quran and Fardhu Ain (J-QAF) programs where students receive not only basic religious-related skills but have an appreciation effect among students. If the J-QAF can be extended to secondary schools it will produce Jawi's skillful memories, choosing a solid foundation of fardhu ain and at the same time the education of the Quran in the broader sense will occur.

\section{Imtiaz Future Planning}

a. Complete the establishment of Imtiaz High School in each district as reservoir future

b. Establishing Imtiaz Primary School as Feeder School

c. Program internationalization of Imtiaz through the introduction of international curriculum Global-Leadership Program.

d. Targeting by 2020 Imtiaz can produce 6000 memories students together with 100 families of a memories with the estimates of each Assembly The state can produce 188 memories by 2020 .

e. Targeting $20 \%$ of SPM candidates to pursue university studies the world's leading. 
f. Implement collaborative programs with local universities for the Fast-Track Program.

g. Establish and empower Imtiaz Alumni Al-Hafiz Council to ensure.

h. Continuity and effectiveness of Ulul Albab Program

i. Imtiaz program socialize through social service activities such as trained head of prayer

j. Strengthen English, Arabic \& Mandarin proficiency

k. Put expert teachers at SMIYT

1. Open the mind of teachers and students through student exchange programs to schools best country and abroad

m. Students should be given training in effective communication

\section{Conclusion}

There are three important factors to develop Islamic civilization over the long term. First epistemology which embodies the whole world of science. Secondly, the growing intellectual tradition. Third capabilities produce human capital with the knowledge and skills to develop the civilization system. Today, the tendency of some Muslim parents in Malaysia to send their children to the cottage and the center of Tahfiz should be for the development of children's potentials so that the knowledge and skills they possess are relevant to the times and challenges they face. They also need a high-level study so that the knowledge they acquire can be beneficial to them so that they continue to contribute towards the development of the Muslims and their civilization. Empowering the Ulul-albab program will produce a brilliant generation, both in terms of world-affairs and in the hereafter in the meantime Muslims have specializations in various disciplines. The young generation is able to learn the human sciences or human sciences by making the Quran a source of reference and will memorize the Quran, studying the science of tafsir and taranum. If all is discussed then Malaysia will emerge as an example country that connects the science of naqli and aqli in an integrative way. It is hoped that efforts to produce balanced human capital and highly-educated Islamic intellectuals from the Ulul-Albab Program will receive the blessings and blessings of Allah SWT as well as the strong support and cooperation of all parties, whether management, administration or parents to adopt the race, religion and the State. 